\title{
The Employment Experience of Refugees in the Netherlands
}

\author{
De Vroome, T., Van Tubergen, F.
}

NOTE: post-print version, April 10, 2010

(post-refereeing, for information see: http://www.sherpa.ac.uk/romeo/issn/0197-9183/) This article may not exactly replicate the final version published in the journal. It is not the copy of record.

The definitive version is available online:

De Vroome, T., Van Tubergen, F. (2010).

The Employment Experience of Refugees in the Netherlands.

International Migration Review, 44 (2), 376-403.

http://dx.doi.org/10.1111/j.1747-7379.2010.00810.x

\begin{abstract}
This study focuses on the economically disadvantaged position of refugees. We use survey data of refugees from Somalia, Iran, Afghanistan, Iraq and the former Yugoslavia in the Netherlands, to analyze refugees' odds of employment and their occupational status. In line with human capital and social capital theory, we find that host country specific education, work experience, language proficiency, and contacts with natives are positively related to the chances of employment and occupational status. The study shows that health problems, integration courses, and the time spent in refugee reception centers form important additional explanations of the economic integration of refugees.
\end{abstract}




\section{Introduction}

As international migration has become an increasingly diverse and widespread phenomenon over the previous decades, many researchers have turned their attention to processes of immigrant integration into new host societies (Castles \& Miller, 2003; Massey et al., 1998). One important aspect of immigrant integration that has received much attention in the literature is economic integration, or the labor market success of immigrants. The study of economic integration of immigrants is highly relevant, as immigrants are often found to hold economically disadvantaged positions in host societies (Van Tubergen, 2006).

Research on the economic disadvantage of immigrants in host societies has mostly focused on labor and family migrants, while relatively few studies have been conducted on the economic experience of refugees. Most population surveys either do not include enough refugees or fail to include the factors that possibly affect their labor market experience, which makes it difficult to properly analyze the economic integration of refugees. The few studies that have been done on refugees are largely restricted to classical immigrant-receiving countries; the United States (Finnan, 1981; Mamgain \& Collins, 2003; Potocky \& McDonald, 1995), Canada (Krahn et al., 2000; Lamba, 2003), and Australia (Waxman 2001), with a particular focus on East-Asian refugees (Waxman 2001). The studies all report an economically disadvantaged position for refugees. To explain the poor economic performance of refugees, researchers have most often focused on human capital theory (i.e. refugees lack employable skills) and social capital theory (i.e. refugees lack resourceful social ties).

In this study, we build on previous research concerning refugees' labor market integration. We include two additional aspects that are not often studied in previous research, but which seem highly relevant in the context of refugees' economic experience. High incidence rates of health problems can form an important explanation of refugees' disadvantaged economic position, as refugees may have experienced war, poverty, and 
political suppression (Väyrynen, 2000). In addition, refugees are subject to admission and integration policies in the host countries, including a possibly prolonged stay in an asylum seeker reception centre and integration courses provided by the government. The effects of such policies on the economic integration of refugees have rarely been examined empirically (Waxman, 2001).

We study the labor market integration of refugees in the Netherlands. Most research has been done in the United States, Australia, and Canada, and little is known about how refugees fare in the Netherlands and in other European countries. European countries form markedly different contexts of immigration; social welfare expenditure is higher and labor markets are more regulated. Moreover, European countries have more ethnically homogenous populations and more exclusive conceptions of national identity, with 'nationalistic arguments' against granting asylum and immigration being expressed among the general public and politicians. The Dutch economic, cultural and political context therefore presents an interesting opportunity to examine the economic integration of refugees. This study allows us to assess the extent to which the processes that determine refugees' labor market success in a European context are similar to the ones found in 'traditional immigration countries' (i.e. the United States, Canada and Australia).

We make use of large-scale survey data including refugees from the former Yugoslavia, Afghanistan, Iran, Iraq and Somalia. Refugees from these origin countries form a significant presence in many destination countries. We focus on the first generation, i.e. refugees who were born outside the Netherlands.

\section{Theory and Hypotheses}

In this article, we use theories addressed in research on the economic incorporation of immigrants. We apply these theories (i.e. human capital theory and social capital theory) to 
the case of refugees. In addition, we come up with factors that seem particularly relevant for the economic integration of refugees (i.e. health problems and admission and integration policies).

\section{Human Capital}

In the literature on the economic incorporation of immigrants in host societies, human capital theory constitutes an important explanation of immigrants' performance in the labor market (Chiswick \& Miller, 2001). The basic assumption of human capital theory is that individual skills determine labor market success. Chiswick and Miller (2001) state that these skills are created through an investment to acquire the skills. A distinction is made between the skills that immigrants have acquired before and after migration; between pre-migration and post-migration human capital (Friedberg, 2000).

Considering the effect of education on economic outcomes, a straightforward proposition is that both pre-migration and post-migration education represent skills that will foster economic integration. However, researchers are increasingly paying attention to the discrepancy between the returns to foreign education and the returns to domestic education (Bratsberg \& Ragan, 2002; Kanas \& Van Tubergen, 2009). Friedberg (2000) has suggested that immigrants will have lower returns to foreign education because of 'differences in quality and compatibility with the host labor market' (Friedberg, 2000: 221). The refugees in this study all come from countries with different and generally less advanced educational systems than the Dutch system, with qualifications that may at times be only partially or not at all recognized by Dutch employers and institutions. We therefore hypothesize that the positive effect of education obtained in the Netherlands on refugees' economic integration will be larger than the effect of foreign education $(\mathrm{H} 1)$.

In this study we also examine two other forms of post-migration human capital. A 
second form of human capital that affects the economic integration of immigrants is proficiency in the host country language. The Dutch language is not spoken in the countries of origin of the refugees in this study, which means that the refugees arrived without any knowledge of the Dutch language. Language skills are an important determinant of immigrants' labor market performance, because reasonable language skills are required for most professions in the host country (Chiswick \& Miller, 2001). Moreover, better language skills enhance immigrants' economic success by increasing the range of jobs in the labor market for which they are qualified (Chiswick \& Miller, 2001). We hypothesize that Dutch language proficiency will positively affect refugees' economic integration (H2).

Labor market experience is a third form of human capital that can affect the economic integration of refugees. The skills acquired 'on the job' can have a positive effect on future employment, because such experience is valued by employers (Chiswick \& Miller, 2009). While this reasoning applies to work experience in the origin and in the destination country, the extent to which pre-migration labor market experience is recognized by employers can be small, because of a limited compatibility with the host society labor market (Chiswick \& Miller, 2009; Friedberg, 2000; Kanas \& Van Tubergen, 2009). In this study, we focus on work experience in the Netherlands. We hypothesize that post-migration labor market experience will positively affect refugees' economic integration (H3).

\section{Social Capital}

According to social capital theory, social contacts provide access to resources that can be helpful in attaining other forms of capital (Portes, 2000). This implies that increased social capital will have a positive effect on economic outcomes. It is argued in the literature that social capital will increase when the individual has more social contacts, when these social contacts have better resources, and when there is more willingness to share resources on the 
part of social contacts (Van Tubergen, 2006).

A key aspect of the resources available through one's network is the information people can provide on the labor market; 'for instance on how to look for jobs, appropriate salaries in different sectors, how to behave towards employers, and other work-related social norms' (Aguilera \& Massey, 2003: 674). The resources may even extend to contacts who know where jobs are available and are willing to use their influence in your favor (Kanas \& Van Tubergen, 2009). Kanas and Van Tubergen (2009) have argued that social contacts with natives - also termed 'bridging social capital' (Putnam, 2000) - may be particularly important in immigrants' economic experience, because natives have naturally been exposed to the host society for a longer time, are generally higher educated, more often employed, and hold more prestigious jobs, rendering them better informed and more influential social contacts (Kanas \& Van Tubergen, 2009).

Previous research has most often focused on immigrants' contacts within the ethnic group or ethnic community (Aguilera \& Massey, 2003; Wilson \& Portes, 1980), in other words 'bonding social capital' (Putnam, 2000). The effect of contacts with natives on the economic integration of immigrants has been much less often examined in empirical research (Kanas \& Van Tubergen, 2009). In this study we focus on bridging social capital, because it is likely that refugees can benefit from the information and influence of Dutch social contacts. We expect that having more social contacts with members of the Dutch majority will positively affect refugees' economic integration (H4).

\section{Health Problems}

While health has been proposed to be an aspect of human capital, as health can be viewed as individual qualities that enhance employability, this approach has received little attention in human capital research (Becker, 2007). Consequently, whether being an aspect of 
human capital or not, health has often been overlooked in analyses of the effect of human capital on economic outcomes among immigrants in general and refugees in particular. In this research, we propose that health problems form an important additional explanation of the economically disadvantaged position of refugees.

Frequently, refugees have experienced violent and traumatic events in their countries of origin (Väyrynen, 2000). In the case of refugees from Iraq, Afghanistan, Somalia and the former Yugoslavia, these circumstances were protracted (civil) wars and accompanying economic embargo's, resulting in severe poverty (Väyrynen, 2000). Iranian refugees are most likely to have fled a situation of intense political suppression, which started after the revolution in 1979 (Ghorashi, 2007). These experiences are potential sources of mental and physical health problems.

Studies have shown that substantial numbers of refugees in the Netherlands report having mental health problems - such as post traumatic stress disorder, depression, anxiety and somatic complaints - and to a lesser extent physical health problems (Gerritsen et al., 2006; Hondius et al., 2000). In two studies on health problems among refugees in the Netherlands - one among Latin American and Middle-Eastern refugees (Hondius et al., 2000), the other among Afghan, Iranian and Somali asylum seekers and refugees (Gerritsen et al., 2006) - adverse events in the respondents' countries of origin were identified as a source of their complaints. Experiences after migration to the Netherlands however, such as inadequate housing, loneliness, and family disruption, are also frequently identified by refugees as a source of their health problems (Gerritsen et al., 2006; Hondius et al., 2000).

We will study the possible consequences of mental health problems in our analysis, by focusing on refugees' health in general and depression in particular. Because of the high incidence rates of mental health problems found in previous research, and because health problems can form an obstacle to finding employment and occupational mobility, we expect 
that general health problems and depression will negatively affect refugees' economic integration (H5).

\section{Admission and Integration Policies}

The individual experiences of refugees with Dutch admission and integration policies form a final set of explanations of refugees' economic integration. In the late 1980's and early 1990's there was a sharp rise in the number of asylum seekers who came to the Netherlands, due to war, poverty and political conflicts. This resulted in strong differences in the amount of time refugees (of different cohorts) stayed in a reception center (Van Selm, 2000). Before acquiring a formal refugee status, asylum seekers can have spent months or even several years in 'application centers', 'asylum seeker centers', and 'research and reception centers'. Awaiting their official refugee status as an asylum seeker, the refugees are 'kept' in relative isolation from the native Dutch population and have only a very limited right to work (Van Selm, 2000). Similar admission policies to those in the Netherlands have been implemented in other European countries as well.

We propose that a relatively long stay in these reception centers can negatively affect the acquisition of post-migration human capital and bridging social capital of refugees, by limiting the opportunities to learn the language, to attend school, and to develop contacts with members of the majority group. Furthermore, a prolonged period in refugee reception centers has been shown to increase physical and mental health problems in a study among Iraqi asylum seekers in the Netherlands (Laban et al., 2004). We expect that a longer stay in a reception centre will negatively affect refugees' economic integration, and that this effect will be mediated by refugees' post-migration human capital, social capital, and health problems (H6).

There are also policies that are designed to help refugees adjust to Dutch society, most 
notably integration courses. Integration courses in the Netherlands have evolved out of language courses for Dutch as a second language that were initiated by volunteers in the 1970 's and 1980's. During the second half of the 1980's and early 1990's, the courses were professionalised and offered by the regional institutions for adult education (ROC's) in the Netherlands. During this period, the integration courses were also expanded to include societal and labor market orientation in addition to the Dutch language courses (Advisory Council on Diversity and Integration, 2008). As of 1998, laws have come into effect that oblige 'newcomers' to participate in integration courses, next to encouraging all other immigrants to follow the courses. This obligation has only partially been enforced however, meaning that a number of (recent) immigrants and refugees have still avoided participation in integration courses. The structure of the integration courses has remained fairly similar after 1998 as it was before. The integration courses take about 600 hours altogether, the bulk of which is spent on language training. Other important aspects of the integration courses are 'societal orientation', 'labor market orientation', and 'societal guidance' which is practical support for newcomers. The integration courses are completed with a test (and accompanying diploma) that concerns the language training and societal orientation parts of the courses (Adriaansens, 2003).

We can expect integration courses to have a beneficial effect on refugees' economic integration, because they represent frequent practice with and increased proficiency in the Dutch language, and a source of information on Dutch society and (access to) the Dutch labor market (Van Den Maagdenberg, 2004). We expect that successful completion of integration courses will positively affect the economic integration of refugees in the Netherlands, and that this effect will be mediated by refugees' post-migration human capital (H7). 


\section{Data and Methods}

\section{Data}

We will base our analysis on the SPVA (Social Position and use of Provisions by Ethnic Minorities) survey data collected in 2003 (Schothorst, 2004). The respondents are refugees from Afghanistan, Iran, Iraq, Somalia, and the former Yugoslavia, who were randomly selected from municipal records in twelve larger cities in the Netherlands. These cities were chosen because of the concentration of these groups in larger cities, in order to reduce survey costs. The respondents were interviewed face-to-face and in the Dutch, English, or French language. Response rates of the groups were between $43 \%$ (former Yugoslavians) and 55\% (Afghans). The sources of non-response showed a similar pattern across the refugee groups, the most important being that about $25 \%$ of the people refused cooperation, about $15 \%$ of the people could not be contacted at the time of data collection, and about $5 \%$ could not participate because of language difficulties. Other sources of nonresponse include respondents for whom the address was incorrect and respondents who were in very bad health or had passed away. Analysis of the data shows that the distribution of the sample across age and gender strongly resembles that of the respective refugee population. Moreover, the distribution across cities of residence is similar between the sample and the population (Schothorst, 2004).

A full questionnaire was presented to the 'heads of household', which were often male 'heads of the family'(68\%). Not all the variables that are included in this study were present in the shorter questionnaire that was used to gather information on the partners. Consequently, information on the time spent in reception centers and on depression is unavailable, as are the measures for Dutch language proficiency and membership of a mainstream (Dutch majority) organization. The dataset includes a total of 3405 first-generation refugees who are heads of household between the ages of 18 and 65, which is the age at which people in the Netherlands 
usually retire. The people with missing information are excluded in this study, because their number is limited (i.e. less than 4\%). All in all, our analyses are based on 3269 heads of household, and 1439 employed respondents are included in the analyses of refugees' occupational status. We will conduct our main analyses with full models on a sample that includes only heads of household, and we will conduct additional analyses with a sample that includes 1056 partners but in which the models are more limited.

Although the data we use are rather unique (i.e. a large-scale survey, including detailed information on key aspects of refugees' economic experience), a disadvantage is the cross-sectional design. Thus, our data do not rule out endogeneity problems, meaning that it is not entirely possible to test the directionality or causality of the relations between independent and dependent variables. The economic experience of refugees is a dynamic process in which (prior) employment also affects refugees' employable skills and social contacts. Panel data are better suited to test the causality of relations, but such studies are rare in the field of refugee integration (Beiser \& Hou, 2001). The use of cross-sectional data is common in research on immigrant integration despite this disadvantage, and it is commonly used among the few studies on the economic integration of refugees as well (e.g. Krahn et al., 2000; Lamba, 2003; Waxman, 2001). Based on cross-sectional data, an important condition for causality - significant association - can be established (Van Tubergen, 2006).

\section{Measurement}

\section{Dependent Variables}

In our first analysis, we use employment as our dependent variable. Those who are currently employed (1) are contrasted with unemployed people, including those who are and those who are not 'seeking' employment (0). The dependent variable in our second analysis is occupational status. All respondents who were employed have described their current 
occupation. Through standardized tools, we have recoded the respondents' occupation into the International Socio-Economic Index (ISEI), which is an internationally comparable measure of occupational status (Ganzeboom, De Graaf, \& Treiman, 1992). ISEI scores represent a continuous approach to occupational stratification and reflect a weighted sum of the average education and average income of occupational groups (Ganzeboom, De Graaf, \& Treiman, 1992). To illustrate, office cleaners and farm workers have a score around 20, nursing personnel a score around 40, and lawyers and medical doctors have a score around 85. We use the ISEI scores, ranging from 16 to 88 , as the dependent variable in our analysis of the occupational status of the employed respondents.

\section{Independent Variables}

For the variable pre-migration education, we use a measure indicating the highest type of education in which the respondent has been enrolled in the country of origin. The measure includes five categories ranging from no education at all, through primary education and lower and higher secondary education, to tertiary education. We use a measure with the same categories for post-migration education, and both are used as interval variables. The number of years of former employment in the Netherlands is used as a measure of post-migration work experience. The measure for Dutch language proficiency is based on the assessment of the interviewer, who has rated the respondent's language proficiency on a three point scale ranging from good to bad. In the analysis, we have contrasted the respondents with good Dutch language proficiency (1) with respondents with reasonable and bad language proficiency (0).

For bridging social capital, we use two measures of social ties with members of the majority population. First, respondents were asked to indicate if they have any Dutch friends. We have contrasted respondents who do not have any Dutch friends (0) with those who do 
have Dutch friends (1). The second measure is organizational membership. Respondents have indicated 'yes or no' when asked if they were a member of an organization. The organizations may include any kind of associations, such as sports, community, and political organizations. Only about $1 \%$ of the reported organizational memberships were with a co-ethnic organization. By organizational membership, we thus mean membership of an organization within the mainstream (Dutch majority) community. We have contrasted respondents who are member of one or more mainstream organizations (1) with respondents who have no organizational memberships (0).

Concerning health problems, a measure consisting of four items is used to indicate depression. Respondents were asked to assess how they felt over the past four weeks. The items were: 'Did you feel calm and relaxed over the past four weeks?', 'Did you feel energetic and were you eager to do things over the past four weeks?', 'Did you feel gloomy and depressed over the past four weeks?' and 'Did you feel nervous and anxious over the past four weeks?'. Participants responded to these questions by stating 'yes', 'sometimes' or 'no'. These items are very similar to those used in the five-item Mental Health Inventory (MHI-5) and the four-item Patient Health Questionnaire (PHQ-4), which assess depression and anxiety (Berwick et al., 1991; Löwe et al., 2009). The four items were recoded in the same direction and then summed and divided by four. Higher values on this measure indicate higher levels of depression. The measure is used as a continuous variable with a scale ranging from one to three. The Cronbach's alpha is .78.

In addition to the depression measure, respondents have been asked to assess their own general health on a five point-scale, ranging from 'very good' to 'very bad'. The measure is treated as an interval variable, with higher values indicating more general health problems. The validity of a single item measure of self-rated health has most often been discussed in studies that analyze the predictive power of the measure with regard to the use of physician 
services and mortality (Idler \& Benyamini, 1997; Miilunpalo et al., 1997). While there is some evidence for modifying effects of factors such as gender and socio-economic status on this measure, authors generally conclude that the single item measure of self-rated health is a valid health status indicator (Miilunpalo et al., 1997; Quesnel-Vallée, 2007; Singh-Manoux et al., 2009).

Respondents were asked if they had ever attended an integration course, and if they had completed it by receiving a diploma. We use four dummy variables representing (1) those who have never attended such a course, (2) those who have completed an integration course through receiving a diploma, (3) those who did attend an integration course but have not received a diploma, and (4) those who are currently enrolled in an integration course. We pay less attention to refugees who have never enrolled in an integration course and those who are currently enrolled, because these categories are rather ambiguous (i.e., possible selectivity of inflow remains unmeasured). We will focus on the contrast between refugees who have successfully completed an integration course and those who did enroll but quit without obtaining a diploma, although we admit that with our cross-sectional data, we are unable to say more about the selectivity of outflow (e.g., are higher skilled people less or more likely to successfully complete an integration course?). Further research is encouraged to examine selectivity of inflow and outflow with panel data.

To estimate the effect of time spent in 'refugee reception centers', we have combined the time spent in three different types of reception facilities. The measure of the time spent in a reception center then indicates the time in years which the respondents have spent in one or more than one of the following three types of reception centers: an application center, a reception center, and/or an asylum seeker center. We use four dummy variables for (1) those who have never been in such a facility, (2) those who have spent up to a year in a reception center, (3) between one and two years, and (4) for those who have spent more than two years 
in a reception center.

We also include several background variables that are potential sources of variation in economic integration and/or have been found to affect economic outcomes in previous research on refugees and immigrants. We include dummy variables representing the country of origin (i.e. Somalia, Afghanistan, Iraq, Iran, and the former Yugoslavia). We also control for the effects of gender, being married, whether the respondent lives in a large city (i.e. a city with more than 250.000 inhabitants) and age. Finally, we include a dummy variable which contrasts refugees who have lived in the Netherlands for ten years or longer (1) with those who have been here for a shorter period (0). The descriptive statistics for the dependent and independent variables are presented in table 1 . The statistics in table 1 are based on the sample of heads of household which is used for the main analyses.

[ Table 1 about here ]

\section{Methods}

In the analysis of employment we use binary logistic regression, and for the analysis of occupational status we use linear regression. Since we use only the employed people from the sample in our analysis of occupational status, selection bias could be a problem because of unmeasured differences between employed and unemployed respondents that are related to their occupational status (Smits, 2003). To correct for selection bias we have used a Heckman two-step procedure for the analysis of occupational status (Smits, 2003). In the selection equation, we have included the variable 'large city' as the selection variable. The selection equation is used to calculate the selection bias control factor Lambda, based on the residuals. The control factor Lambda is added in the analysis of occupational status. The parameter estimates are then calculated with Ordinary Least Squares (OLS) regression, and weights are 
constructed to obtain corrected standard errors through Weighted Least Squares (WLS) regression. We have used the statistical program STATA 10 to estimate our models.

\section{Results}

We have used a stepwise approach with two subsequent models for the analyses of both employment and occupational status. At the first step (model 1 and 3), the variables that indicate the time spent in reception centers, the integration courses, pre-migration education and occupational status abroad, and the background variables are included. Then at the second step (model 2 and 4), the post-migration education and work experience, language proficiency, social capital variables, and health variables are added. This is done because we hypothesize that the relations between staying in a reception center and successfully completing an integration course with the dependent variables employment and occupational status are mediated by post-migration education and work experience, Dutch language proficiency, bridging social capital, and health problems. We will focus on the analyses of employment and occupational status among heads of household. The results of these analyses are presented in table $2{ }^{1}$

[ Table 2 about here ]

\section{Human Capital}

We hypothesized that both foreign education and education in the Netherlands will positively affect the economic integration of refugees, and that the positive effect of education in the Netherlands will be larger than the effect of foreign education (H1). Results show that foreign education is significantly related to employment (model 2) and occupational status (model 4). A standard deviation increase in education abroad is associated with an increase in 
refugees' odds of employment by about $1.1\left(e^{.100 * 1.318}\right)$. An increase of one standard deviation in education abroad is associated with an increase of $3.949(2.996 \times 1.318)$ status points. We find that education obtained in the Netherlands is significantly associated with the odds of being employed. Each standard deviation increase in education in the Netherlands is associated with an increase in refugees' odds of employment by about $1.2\left(e^{.147^{*} 1.209}\right)$. Education obtained in the Netherlands is also significantly and positively related to refugees' occupational status (model 4). Each standard deviation increase in domestic education is associated with an increase of $4.387(3.629 \times 1.209)$ status points. The results are in line with our hypothesis; both foreign education and education in the Netherlands are significantly and positively related to employment and occupational status, and the relations are stronger for education obtained in the Netherlands.

We hypothesized that Dutch language proficiency will positively affect refugees' economic integration (H2), and we find evidence in support of this hypothesis. Though language proficiency is not significantly associated with refugees' odds of employment (model 2), it is significantly related to refugees' occupational status (model 4). The occupational status of refugees that speak the Dutch language well is increased by 3.867 status points, when contrasted with refugees who have only reasonable or poor command of the language.

It was hypothesized that post-migration labor market experience will positively affect refugees' economic integration (H3). Results show that labor market experience in the Netherlands is positively related to refugees' chances of employment. One standard deviation increase in Dutch labor market experience is associated with $1.7\left(e^{.117^{* 4.776}}\right)$ times higher odds of being employed. We also find a significant relation between labor market experience in the Netherlands and refugees' occupational status (model 4). Each standard deviation increase in labor market experience is associated with an increase of $3.553(.744 \times 4.776)$ status points. 
Our hypothesis is thus confirmed.

\section{Social Capital}

Regarding bridging social capital, we hypothesized that having more social contacts with the Dutch majority will positively affect refugees' economic integration (H4). We have operationalized bridging social capital in two ways; as having Dutch friends, and as being a member of a mainstream organization. We find that having Dutch friends is significantly and positively related to refugees' odds of employment and occupational status. The odds of employment are $1.4\left(e^{.321}\right)$ times higher for refugees who do have Dutch friends (model 2). The occupational status of those who do have Dutch friends is 4.130 status points higher than the status of respondents who do not have Dutch friends (model 4). We also find that being a member of a mainstream organization is positively and significantly related to refugees' occupational status. The occupational status of refugees who are member of a mainstream organization is 2.467 status points higher than the status of refugees who have no organizational memberships. We thus find evidence in support of our fourth hypothesis; we can state that having more social contacts with the Dutch majority is positively related to refugees' economic integration, because having Dutch friends is positively associated with the odds of employment, and both having Dutch friends and mainstream organizational membership are positively associated with refugees' occupational status.

\section{Health}

We expected that depression and general health problems will negatively affect refugees' economic integration (H5). In accordance with our hypothesis, we find that depression has a significant negative association with the odds of employment (model 2) and occupational status (model 4). One standard deviation increase on the depression scale is 
associated with a decrease by about $.9\left(e^{-.192 * 659}\right)$ in refugees' odds of employment. A standard deviation increase in depression is associated with a decrease of $1.390(2.110 \times .659)$ status points. General health problems are also found to be significantly and negatively related to both the odds of employment and occupational status. One standard deviation increase on the scale of general health problems is associated with a decrease by about $.8\left(e^{-.274 * 1.043}\right)$ in the odds of employment. A standard deviation increase in general health problems is associated with a decrease of 4.121 (3.951 x 1.043) status points. Our fifth hypothesis is thus confirmed.

\section{Admission and Integration Policies}

We hypothesized that a longer stay in a reception centre will negatively affect refugees' economic integration, and that this effect would be partially explained by refugees' post-migration human capital, social capital, and health problems (H6). To test the hypothesis, we have first estimated the relation between the time spent in reception centers and the dependent variables employment and occupational status. Our results show that having spent time in a reception center is indeed significantly and negatively related to refugees' odds of employment and occupational status (models 1 and 3). This suggests that refugees who have stayed in a reception center for a longer period are on average more often unemployed, and when they are employed they tend to occupy lower status positions.

When the variables reflecting post-migration human capital, bridging social capital, and health problems are included (models 2 and 4), we see that the relations between staying in a reception center and employment are no longer significant. The relations between staying in a reception center and occupational status are also reduced, and only the contrast between having stayed in a reception center for more than two years and the reference category remains significant. Our results suggest that the negative relation between staying in a 
reception center and refugees' odds of employment is mediated by post-migration human capital, bridging social capital, and health problems (model 2).

Additional analyses show that it is almost exclusively the post-migration human capital variables (i.e. education and work experience in the Netherlands and proficiency in the Dutch language) that mediate the relation between staying in a reception center and employment, not social capital or health problems. ${ }^{2}$ This means that those people who have stayed for a longer time period in a refugee reception center have lower odds of employment and hold lower status positions because they have acquired fewer post-migration human capital (i.e., less education, work experience and language proficiency) than those people who did not stay in a reception center or for a shorter period. When we look at refugees who have stayed in a reception center for more than two years compared to refugees who did not stay in a reception center, in total about 80 percent $((.526-.106) / .526)$ of the original relation with employment and about 64 percent $((11.800-4.203) / 11.800)$ of the original relation with occupational status is explained by the mediating variables.

We expected that successful completion of integration courses would positively affect the economic integration of refugees in the Netherlands, and that this effect would be mediated by refugees' post-migration human capital (H7). We focus on the contrast between those refugees who have successfully completed an integration course (those who have obtained a diploma) and refugees' who did enroll in an integration course but have quit without obtaining the diploma. We pay less attention to refugees who have never enrolled in an integration course and those who are currently enrolled, because these categories are rather ambiguous. In line with our hypothesis, the results show that dropping out of an integration course is associated with a decrease in refugees' odds of employment by about $.7\left(e^{-.330}\right)$ and a decrease of 8.343 occupational status points, when contrasted with respondents who have successfully completed an integration course. 
The relation between dropping out of an integration course and the odds of employment is no longer significant when post-migration human capital variables, bridging social capital, and health variables are included (model 2). The relation between dropping out of an integration course and occupational status remains significant but is reduced in strength (model 4). This indicates that the relation between successfully completing an integration course and refugees' odds of employment and occupational status is mediated by postmigration human capital, bridging social capital, and health problems. As additional analyses show, it is almost exclusively the post-migration human capital variables (i.e. education and work experience in the Netherlands and proficiency in the Dutch language) that mediate the relation between dropping out of an integration course and refugees' odds of employment and

occupational status. ${ }^{3}$ This suggests that those people who have dropped out of an integration course are more often unemployed because they have acquired less host-country education, work experience and language proficiency than those people who have successfully completed an integration course.

\section{Control Variables}

We have used dummy variables to analyze the relation between refugees' origin country and their economic success, with Afghanistan as the reference category. Results show that refugees from Somalia fare especially poorly. From model 4, it can be seen that refugees from Somalia score on average 9.416 points lower on the occupational status scale, when compared to refugees from Afghanistan, even after controlling for variables measuring human capital, social capital, health problems and admission and integration policies. Male respondents have higher odds of being employed (models 1 and 2). The initial positive relation between being male and occupational status (model 3) is no longer significant when the variables for human capital, social capital and health are included in model 4. A length of 
stay in the Netherlands of more than ten years is positively associated with employment and occupational status when contrasted with a shorter length of stay in the Netherlands, and age is negatively related to employment and occupational status. There is no significant relation between being married and refugees' economic success.

\section{Conclusion and Discussion}

Few studies have analyzed the economic integration of refugees, and most of these were conducted in classical immigration countries (i.e. Australia, Canada, and the United States). Because of cultural, economic and political differences, it is important to examine to what extent the processes that influence the labor market success of refugees in classical immigrant countries are similar to processes of refugee adaptation in European nations. In this research, we have studied the economic integration of Somali, Iraqi, Afghani, Iranian and exYugoslavian refugees in the Netherlands. Our main aim was to offer explanations for the economically disadvantaged position of this group. We have studied the employment and occupational status of more than 3000 male and female refugees between the ages of 18 and 65. We have analyzed the extent to which 'well-established' explanations of the economic integration of immigrants and refugees (i.e. human capital theory and social capital theory) play a role in the economic integration of refugees in the Netherlands. Furthermore, we have tested two additional sets of explanations (i.e. health problems and admission and integration policies) which are not often accounted for in studies on the economic integration of refugees.

Results show that among refugees in the Netherlands, education acquired in the host country is a more important predictor of employment than education acquired abroad. We find that both education acquired in the host country and education acquired abroad contribute to refugees' economic integration, with stronger relations for education obtained in the host country. This study adds to a recent discussion in the literature on immigrant integration, 
which concerns the 'international transferability' of immigrants' human capital, and especially the relatively meager returns to the skills acquired before migration (Bratsberg \& Ragan, 2002; Friedberg, 2000; Kanas \& Van Tubergen, 2009). In previous studies in Canada (Krahn et al., 2000; Lamba, 2003) and Australia (Waxman, 2001), it has been shown that among refugees in particular, the 'international transferability' of educational qualifications can be limited. We conclude that refugees in the Netherlands face similar barriers when it comes to recognition of their educational qualifications as refugees and immigrants in other (classical immigrant receiving) countries. This means that refugees have potential resources from which both refugees themselves and society at large can benefit more when the recognition of foreign qualifications is facilitated, for instance through occupational specific language training. The results also imply that policy makers would do well to stimulate refugees to educate themselves in the host country, and to provide opportunities for doing so, when aiming for a better economic integration of refugees.

The importance of the acquisition of post-migration human capital is also evident from two other forms of capital. We find that Dutch language proficiency and work experience in the Netherlands are also correlated with the economic integration of refugees. Our results show that Dutch language proficiency and work experience in the Netherlands play an important role in the economic incorporation of refugees. These results are in line with previous research in which labor market experience and language proficiency in destination countries have been found to positively affect the economic integration of immigrants (Chiswick \& Miller, 2009; Van Tubergen, 2006) and refugees in classical immigrant receiving countries (Mamgain \& Collins, 2003; Potocky \& McDonald, 1995; Waxman, 2001). Our results indicate that prior work experience in the host country is crucial for refugees' economic success. Prior work experience in the host country will enhance refugees' odds of staying in employment and attaining higher status positions. Policies that aim to foster 
language proficiency and labor market participation, such as language training and programs that offer assistance in finding employment, will likely have a lasting positive effect on refugees' economic experience.

Besides human capital, our study also emphasizes the role of bridging social capital. We find that social contacts with members of the majority population, and more specifically having Dutch friends, can positively affect refugees' economic integration. Furthermore, our results indicate that membership of a mainstream organization is positively associated with refugees' economic integration. Researchers have argued that contacts with natives can be particularly important in the economic experience of immigrants, because natives can be a valuable source of 'country-specific' information and other resources (Kanas \& Van Tubergen, 2009). Our findings show that this reasoning also applies to the experience of refugees in a European context.

Most studies that include social capital as an explanation of economic outcomes among immigrants have focused on the extent to which immigrants employ social contacts with family and with other co-ethnics to get ahead in the labor market (Aguilera \& Massey, 2003; Ross-Sheriff, 2001; Wilson \& Portes, 1980). These studies have shown that co-ethnic ties can be an important resource for immigrants and refugees. Though the data did not allow us to assess the effect of co-ethnic social contacts on refugees' economic success, future studies would do well to include co-ethnic ties as well as ties with the native majority in their analyses. Further research is also encouraged to study the role of bridging social capital more extensively, for instance by looking at the resources of the social contacts and at refugees' opportunities to engage in social relations with the majority population. This enables a further understanding of the quality of the resources obtained through the relationship and the barriers to building social networks that refugees are confronted with, such as their language proficiency and exclusive attitudes on the part of majority members. 
Our results clearly show that general health problems and depression are negatively associated with the economic integration of refugees. While several studies have shown that incidence rates of mental and physical health problems are relatively high among refugees (Gerritsen et al., 2006; Hondius et al., 2000), the relation between health problems and the economic success of refugees has not often been studied (Gernaat et al., 2002). Based on the results of this study, we can state that refugees' health can be an important barrier to successful economic incorporation into the host country.

We have also studied the role of the time refugees have spent in refugee reception centers, which is an aspect of the process of admission to the Netherlands. Our results reveal that a longer stay in refugee reception centers is negatively related to refugees' economic integration into the Netherlands. As hypothesized, the relation between staying in reception centers and employment is largely explained when variables indicating post-migration human capital, social contacts with natives, and health problems are included in the model. Additional analyses show that the relation between staying in reception centers and employment is mainly mediated by the post-migration human capital variables. This means that we find that a prolonged stay in a reception center reduces refugees' odds of employment and occupational status, by preventing them from acquiring post-migration education, work experience and language skills, and to a lesser extent by preventing them from acquiring (bridging) social contacts and by causing health problems.

A limitation of the present study is that we only have information on health at the moment of the survey, not during refugees' stay in the reception centers or between that time and the time of the survey. As research shows that the time spent in a reception center and health problems are strongly related (Laban et al., 2004), this line of inquiry should be pursued more extensively in future research. The relation between staying in a reception center and occupational status is not fully explained by human capital, social capital and 
health variables, which indicates that it is useful to investigate the negative effect of staying in reception centers on refugees' economic success more extensively in future research. Policy makers could reduce the time refugees spend in reception centers in order to prevent that the well-being and productivity of refugees is harmed by these policies.

Turning to the role of integration courses, we find that successfully completing an integration course (by obtaining a diploma) is positively associated with the economic integration of refugees, when refugees who have successfully completed an integration course are contrasted with refugees who have enrolled in an integration course but did not manage to obtain a diploma. This means that refugees who have successfully completed an integration course have higher odds of employment and, when employed, hold higher status job positions. The initial positive relation between having obtained an integration course diploma and refugees' economic integration is largely explained when accounting for the postmigration variables, as we had hypothesized. Moreover, additional analyses show that the relation between having obtained the diploma and employment is mainly mediated by the post-migration human capital variables. This means that we find that successfully completing an integration course is positively associated with the economic integration of refugees, through a positive correlation with Dutch language proficiency and with education and work experience in the Netherlands. The integration programs appear to do what they are designed for to some extent, by improving refugees' proficiency in the Dutch language. The help with refugees' orientation on the labor market (e.g. job searching techniques) and orientation in society (e.g. help with bureaucratic institutions and information on rules of conduct) may be reflected in refugees' work experience.

Though they are not the main focus of our research, two of the control variables should be discussed. First, we find that the positive relation between being male and occupational status is not significant in the full model. The results suggest that the relation 
between gender and occupational status can be largely explained by human capital, social capital and health problems, which means that men occupy higher status positions because they have more human and social capital and less health problems. Second, there is a stark contrast between the refugees from Somalia and refugees from other origin countries. The results indicate that refugees from Somalia fare very poorly. Because Somali's are the most distinct group due to skin color, a possible explanation is discrimination. A good measure of discrimination was unfortunately unavailable in the data, so we were unable to test this explanation. Another explanation is that a relatively large portion of Somali's who came to the Netherlands has since moved to another country, mostly the United Kingdom and the United States (Van Den Reek \& Hussein, 2003). There can be selectivity in terms of education and other resources for the group of Somali's which has left the Netherlands, which could help explain the relatively disadvantaged position of Somali's in the Netherlands.

In conclusion, our findings show that post-migration human capital and bridging social capital are important in explaining employment and occupational status among refugees in the Netherlands. The study also shows that health problems, staying in refugee reception centers, and integration courses form important additional explanations of the economic integration of refugees. 


\section{References}

Adriaansens, H. P. M. (Ed.)

2003 Integration: an educational challenge for newcomers, state, and society. Den Haag: Council for Societal Development.

Advisory Council on Diversity and Integration

2008 Integration Practice in Amsterdam: High Ambitions, Low Returns. Amsterdam: City Hall Press.

Aguilera, M. \& Massey, D.

2003 "Social Capital and the Wages of Mexican Migrants: New Hypotheses and Tests." Social Forces 82:671-701.

Becker, G.S.

2007 "Health as Human Capital: Synthesis and Extensions." Oxford Economic Papers $59: 379-410$

Beiser, M. \& Hou, F.

2001 "Language Acquisition, Unemployment and Depressive Disorder among Southeast Asian Refugees: A 10-Year Study.” Social Science and Medicine 53:1321- 1334.

Berwick, D.M., Murphy, J.M., Goldman, P.A., Ware, J.E., Barsky, A.J. \& Weinstein, M.C.

1991 "Performance of a Five-Item Mental Health Screening Test." Medical Care 29:169176.

Bratsberg, B. \& Ragan, J. F.

2002 "The Impact of Host-Country Schooling on Earnings: A study of Male Immigrants in the United States.” The Journal of Human Resources 37:63-105.

Castles, S. \& Miller, M. J.

2003 The Age of Migration: International Population Movements in the Modern World. New York: The Guilford Press. 
Chiswick, B. R. \& Miller, P. W.

2001 “A Model of Destination-Language Acquisition: Application to Male Immigrants in Canada.” Demography 38:391-409.

Chiswick, B. R. \& Miller, P. W.

2009 “The International Transferability of Immigrants' Human Capital Skills.” Economics of Education Review 28:162-169.

Finnan, C. R.

1981 “Occupational Assimilation of Refugees." International Migration Review 15:292309.

Friedberg, R. M.

2000 "You Can't Take It With You? Immigrant Assimilation and the Portability of Human Capital." Journal of Labor Economics 18:221-251.

Ganzeboom, H. B. G., De Graaf, P. M. \& Treiman, D. J.

1992 “A Standard International Socio-Economic Index of Occupational Status.” Social Science Research 21:1-56.

Gernaat, H.B.P.E., Malwand, A.D., Laban, C.J., Komproe, I. \& De Jong, J.T.V.M.

2002 "Many Psychiatric Disorders among Afghan Refugees with a Residence Status in Drenthe, the Netherlands, in Particular Depressive and Posttraumatic Stress Disorders; Community-Based Study. Nederlands Tijdschrift voor Geneeskunde 146:1127-1131. (in Dutch, abstract in English).

Gerritsen, A., Bramsen, I., Devillé, W., Van Willegen, L., Hovens, J, Van Der Ploeg, H.

2006 "Physical and Mental Health of Afghan, Iranian and Somali Asylum Seekers and Refugees Living in the Netherlands." Social Psychiatry and Psychiatric Epidemiology 41:18-26.

Ghorashi, H. 
2007 “Giving Silence a Chance: The Importance of Life Stories for Research on Refugees." Journal of Refugee Studies 21:117-132.

Hondius, A., Van Willigen, L., Kleijn, W. C. \& Van der Ploeg, H. M.

2000 "Health Problems Among Latin-American and Middle-Eastern Refugees in the Netherlands: Relations with Violence Exposure and Ongoing Socio-Psychological Strain.” Journal of Traumatic Stress 13:619-634.

Idler, E.I. \& Benyamini, Y.

1997 "Self-Rated Health and Mortality: A Review of Twenty-Seven Community Studies." Journal of Health and Social Behavior 38:21-37.

Kanas, A. \& Van Tubergen, F.

2009 "The Impact of Origin and Host Country Schooling on the Economic Performance of Immigrants." Social Forces, 88:893-915.

Krahn, H., Derwing, T., Mulder, M., \& Wilkinson, L.

2000 "Educated and Underemployed: Refugee Integration into the Canadian Labour Market.” International Journal of Migration and Integration 1:59-84.

Laban, C. J., Gernaat, H.B.P.E., Komproe, I. H., Schreuders, B.A. \& De Jong, J.

2004 "Impact of a Long Asylum Procedure on the Prevalence of Psychiatric Disorders in Iraqi Asylum Seekers in The Netherlands." Social Psychiatry and Psychiatric Epidemiology 43:507-515.

Lamba, N. K.

2003 "The Employment Experiences of Canadian Refugees: Measuring the Impact of Human and Social Capital on Quality of Employment." Canadian Review of Sociology and Anthropology 40:45-64.

Löwe, B., Wahl, I., Rose, M., Spitzer, C., Glaesmer, H., Wingenfeld, K., Schneider, A. \& Brähler, E. 
2010 “A 4-Item Measure of Depression and Anxiety: Validation and Standardization of the Patient Health Questionnaire-4 (PHQ-4) in the General Population." Journal of Affective Disorders, 122:86-95.

Mamgain, V. \& Collins, K.

2003 "Off the Boat, Now Off to Work: Refugees in the Labour Market in Portland Maine." Journal of Refugee Studies 16:113-140.

Massey, D. S., Arango, J., Hugo, G., Kouaouci, A., Pellegrino, A. \& Taylor, J. E.

1998 Worlds in Motion. Understanding International Migration at the End of the Millennium. Oxford: Clarendon Press.

Miilunpalo, S., Vuori, I., Pekka, O., Pasanen, M. \& Urponen, H.

1997 "Self-Rated Health Status as a Health Measure: The Predictive Value of Self-Reported Health Status on the Use of Physician Services and on Mortality in the Working-Age Population.” Journal of Clinical Epidemiology 50:517-528.

Portes, A.

2000 “The Two Meanings of Social Capital.” Sociological Forum 15:1-12.

Potocky, M. \& McDonald, T.

1995 "Predictors of Economic Attainment of Southeast Asian Refugees: Implications for Service Improvement.” Social Work Research 19:219-228.

Putnam, R. D.

2000 Bowling alone: the collapse and revival of American community. New York: Simon \& Schuster.

Quesnel-Vallée, A.

2007 "Self-Rated Health: Caught in the Crossfire of the Quest for 'True' Health?" International Journal of Epidemiology 36:1161-1164.

Ross-Sheriff, F. 
2001 "Immigrant Muslim Women in the United States: Adaptation to American Society." Journal of Social Work Research 2:283-294.

Schothorst, Y.

2004 SPVA-2003. Verslag van het veldwerk onder vijf groepen allochtonen. Amsterdam: Veldkamp.

Singh-Manoux, A., Martikainen, P., Ferrie, J., Zins, M. Marmot, M. \& Goldberg, M.

2009 "What Does Self Rated Health Measure? Results From the British Whitehall II and French Gazel Cohort Studies." Journal of Epidemiology and Community Health $60: 364-372$.

Smits, J.

2003 "Estimating the Heckman Two-Step Procedure to Control for Selection Bias with SPSS.”Jeroen Smits'website: http://home.planet.nl/ >smits.jeroen.

Van Den Maagdenberg, V. (Ed.).

2004 Jaarrapport Integratie 2004. Rotterdam: ISEO.

Van Den Reek, E.W.A. \& Hussein, A.I.

2003 Somali's in Transit: Moving behavior of Dutch Somali's to England. Tilburg: Wetenschapswinkel Universiteit van Tilburg. (in Dutch)

Van Selm, J.

2000 "Asylum in the Netherlands: A Hazy Shade of Purple." Journal of Refugee Studies $13: 74-90$.

Van Tubergen, F.

2006 Immigrant Integration: A Cross-National Study. New York: LFB Scholarly Publishing LLC.

Väyrynen, R.

2000 "Weak States and Humanitarian Emergencies: Failure, Predation, and Rent-Seeking." 
In E.W. Nafziger, F. Stewart \& R. Väyrynen (Eds.), War, Hunger, and Displacement. The Origins of Humanitarian Emergencies (Vol. 2, pp. 437-479). Oxford: Oxford University Press.

Waxman, P.

2001 "The Economic Adjustment of Recently Arrived Bosnian, Afghan and Iraqi Refugees in Sydney, Australia. International Migration Review 35:472-505.

Wilson, K. L. \& Portes, A.

1980 "Immigrant Enclaves: An Analysis of the Labor Market Experiences of Cubans in Miami." American Journal of Sociology 86:295-319. 


\begin{tabular}{|c|c|c|c|}
\hline & Range & Mean & SD \\
\hline \multicolumn{4}{|l|}{ Dependent variable } \\
\hline Employed & $0 / 1$ & .4402 & \\
\hline Occupational Status & $16-88$ & 39.3482 & 15.57682 \\
\hline \multicolumn{4}{|l|}{ Independent Variables } \\
\hline \multicolumn{4}{|l|}{ Admission and Integration Policies } \\
\hline \multicolumn{4}{|l|}{ Years in reception centre } \\
\hline Not at all & $0 / 1$ & .2897 & \\
\hline $0-1$ yrs & $0 / 1$ & .5255 & \\
\hline $1-2$ yrs & $0 / 1$ & .1190 & \\
\hline More than 2 yrs & $0 / 1$ & .0658 & \\
\hline \multicolumn{4}{|l|}{ Integration course } \\
\hline Never followed & $0 / 1$ & .5087 & \\
\hline Yes, with diploma & $0 / 1$ & .2903 & \\
\hline Yes, no diploma & $0 / 1$ & .1322 & \\
\hline Yes, currently enrolled & $0 / 1$ & .0688 & \\
\hline \multicolumn{4}{|l|}{ Human Capital } \\
\hline$\overline{\text { Education abroad }}$ & $0-4$ & 2.2157 & 1.31800 \\
\hline Education in the Netherlands & $0-4$ & .6531 & 1.20873 \\
\hline Work experience in the Netherlands & $0-40$ & 3.0058 & 4.77553 \\
\hline High Dutch language proficiency & $0 / 1$ & .6525 & \\
\hline \multicolumn{4}{|l|}{ Social Capital } \\
\hline$\overline{\text { Dutch friends }}$ & $0 / 1$ & .7430 & \\
\hline Member of a mainstream organization & $0 / 1$ & .1820 & \\
\hline \multicolumn{4}{|l|}{ Health } \\
\hline$\overline{\text { General health problems }}$ & $1-5$ & 2.2300 & 1.04300 \\
\hline Depression & $1-3$ & 1.7401 & .65909 \\
\hline \multicolumn{4}{|l|}{ Control Variables } \\
\hline \multicolumn{4}{|l|}{ Country of origin } \\
\hline Afghanistan & $0 / 1$ & .2050 & \\
\hline Iraq & $0 / 1$ & .2031 & \\
\hline Iran & $0 / 1$ & .2068 & \\
\hline Former Yugoslavia & $0 / 1$ & .1878 & \\
\hline Somalia & $0 / 1$ & .1887 & \\
\hline Male & $0 / 1$ & .6757 & \\
\hline More than 10 years in the Netherlands & $0 / 1$ & .5317 & \\
\hline Age & $18-64$ & 36.5500 & 9.99300 \\
\hline Married & $0 / 1$ & .4956 & \\
\hline Large city & $0 / 1$ & .5072 & \\
\hline
\end{tabular}


Table 2. Regression Analyses of Employment and Occupational Status among Refugees

\begin{tabular}{|c|c|c|c|c|c|c|c|c|}
\hline & \multicolumn{4}{|c|}{ Employment } & \multicolumn{4}{|c|}{ Occupational Status } \\
\hline & \multicolumn{2}{|c|}{ Model 1} & \multicolumn{2}{|c|}{ Model 2} & \multicolumn{2}{|c|}{ Model 3} & \multicolumn{2}{|c|}{ Model 4} \\
\hline & B & S.E. & B & S.E & B & S.E. & B & S.E \\
\hline \multicolumn{9}{|c|}{ Admission and Integration Policies } \\
\hline \multicolumn{9}{|c|}{ Years in reception centre } \\
\hline None (ref.) & 0 & & 0 & & 0 & & 0 & \\
\hline $0-1$ yrs & $-.195 * *$ & .054 & .059 & .061 & $-4.353 * *$ & 1.135 & -.864 & 1.008 \\
\hline $1-2$ yrs & $-.300 * *$ & .079 & .042 & .087 & $-7.227 * *$ & 1.684 & -1.670 & 1.487 \\
\hline More than 2 yrs & $-.526^{* *}$ & .104 & -.106 & .114 & $-11.800 * *$ & 2.290 & $-4.203 *$ & 2.031 \\
\hline \multicolumn{9}{|l|}{ Integration course } \\
\hline Yes, with diploma (ref.) & 0 & & 0 & & 0 & & 0 & \\
\hline No, never followed & -.054 & .053 & $-.158 *$ & .058 & -.585 & 1.103 & -.400 & .978 \\
\hline Yes, but no diploma & $-.330 * *$ & .077 & -.127 & .084 & $-8.343 * *$ & 1.670 & $-2.906^{*}$ & 1.472 \\
\hline Yes, currently enrolled & $-.771 * *$ & .115 & $-.609 * *$ & .124 & $-18.323 * *$ & 2.719 & $-10.311 * *$ & 2.472 \\
\hline \multicolumn{9}{|l|}{ Human Capital } \\
\hline Education abroad & $.132 * *$ & .019 & $.100 * *$ & .022 & $4.241 * *$ & .405 & $2.996 * *$ & .366 \\
\hline Education in NL & & & $.147 * *$ & .022 & & & $3.629 * *$ & .325 \\
\hline Work experience in NL & & & $.117 * *$ & .008 & & & $.744 * *$ & .116 \\
\hline Good Language proficiency & & & .076 & .061 & & & $3.867 * *$ & 1.090 \\
\hline \multicolumn{9}{|l|}{ Social Capital } \\
\hline Dutch friends & & & $.321 * *$ & .064 & & & $4.130 *$ & 1.197 \\
\hline Mainstream organization & & & .059 & .063 & & & $2.467 *$ & 1.002 \\
\hline \multicolumn{9}{|l|}{ Health Problems } \\
\hline General health problems & & & $-.274 * *$ & .030 & & & $-3.951 * *$ & .545 \\
\hline Depression & & & $-.192 * *$ & .044 & & & $-2.110 *$ & .750 \\
\hline \multicolumn{9}{|l|}{ Control Variables } \\
\hline \multicolumn{9}{|l|}{ Country of origin } \\
\hline Afghanistan (ref.) & 0 & & 0 & & 0 & & 0 & \\
\hline Iraq & $-.222 *$ & .070 & $-.176^{*}$ & .076 & -2.081 & 1.522 & -.892 & 1.335 \\
\hline Iran & $.151^{*}$ & .075 & -.024 & .083 & $6.552 * *$ & 1.571 & 2.601 & 1.373 \\
\hline Former Yugoslavia & $.347 * *$ & .078 & .067 & .086 & $4.823 *$ & 1.624 & -.878 & 1.406 \\
\hline Somalia & $-.430 * *$ & .080 & $-.497 * *$ & .087 & $-9.719 * *$ & 1.734 & $-9.416^{* *}$ & 1.539 \\
\hline Male & $.508 * *$ & .054 & $.289 * *$ & .060 & $8.376^{* *}$ & 1.267 & 1.774 & 1.073 \\
\hline More than 10 yrs. in NL & $.455^{* *}$ & .052 & .061 & .061 & $10.081 * *$ & 1.134 & $2.752 *$ & 1.025 \\
\hline Age & $-.026 * *$ & .003 & $-.021 * *$ & .003 & $-.496 * *$ & .059 & $-.189 *$ & .060 \\
\hline Married & .065 & .048 & .070 & .054 & -.629 & 1.017 & -.422 & .888 \\
\hline \multicolumn{9}{|l|}{ Selection Variable } \\
\hline Large city & $.123 *$ & .045 & $.166^{*}$ & .050 & .650 & .953 & 1.202 & .836 \\
\hline Lambda & & & & & 20.733 & .697 & 15.853 & .705 \\
\hline Constant & .127 & .120 & $.394^{*}$ & .168 & $21.779 * *$ & 2.636 & $23.681 * *$ & 3.000 \\
\hline Wald chi ${ }^{2}$ & 512 & & 691 & & 512 & & 691 & \\
\hline Df & 16 & & 23 & & 16 & & 23 & \\
\hline Log likelihood & -7702 & & -7291 & & -7702 & & -7291 & \\
\hline $\mathrm{N}$ & 3269 & & 3269 & & 1439 & & 1439 & \\
\hline
\end{tabular}

$* * \mathrm{p}<.001 ; * \mathrm{p}<.05$ (one-tailed test for hypothesized effects)

Note: Unstandardized coefficients. Results are based on the Heckman two-step procedure. The variable 'large city' is included in the analysis as the selection variable for the selection equation. The control factor Lambda is added in the analysis of occupational status. 


\section{Footnotes}

\footnotetext{
${ }^{1}$ The results of the additional (limited) analyses on the sample including partners lead to the same substantive conclusions as the results of the main analyses. The results of the additional analyses are available upon request from the authors.
}

${ }^{2}$ We have conducted additional analyses in which we include either post-migration human capital variables, or bridging social capital variables, or health variables, in models 2 and 4. Furthermore, we have conducted analyses in which we have included all combinations of two of these three sets of mediating variables (human capital and social capital, human capital and health problems, and social capital and health problems). The results of the additional analyses can be obtained from the authors on request.

${ }^{3}$ The additional analyses that are referred to here are described under footnote 2 . 